\author{
ANATOLIJ VOVK, \\ National University of Life and Environmental Sciences of Ukraine (Kyiv, Ukraine) \\ e-mail:vovkanatolij2021@gmail.com,ORCID 0000-0002-3636-3773
}

\title{
INTERPRETATIONS OF THE PHILOSOPHICAL LEGACY OF VOLODYMYR SHYNKARUK IN THE WORKS OF VITALII TABACHKOVSKYI
}

\begin{abstract}
The emergence of various interpretations of the legacy of Volodymyr Shynkaruk is caused not only by the texts of the classic of modern Ukrainian philosopher and facts from the history of philosophical thought development in Ukraine in the second half of the 20th century, but also by the struggle of various narratives that already exist or are offered by philosophers to tell about the fate of philosophy in Kyiv in Soviet and post-Soviet times. The discussion about the identity of Volodymyr Shynkaruk's philosophy arose in the late 1990s and early 2000s in connection with the publication by V.H. Tabachkovskyi of a number of articles and chapters in books devoted to the interpretation of the figure of V. Shynkaruk as the founder of the Kyiv anthropological school. Vitalii Tabachkovskyi tried to substantiate and reveal a certain narrative about the Kyiv Philosophical School as the central mainstream in the philosophical sixties, as well as a narrative about the phenomenon of philosophical sixties as a kind of manifestation of liberalism and dissidence regarding the official ideology and philosophy. Many distortions of the true meaning of the texts of Kyiv philosophers occurred through reading them not in their own context and meanings, but through guessing what similar philosophical concepts are in world thought. Vitalii Tabachkovskyi's method of analogies and his attempts to look at Volodymyr Shynkaruk's work through the prism of analogies with modern trends develop in his book and many articles. Despite the desire to positively accept Vitalii Tabachkovskyi's reasoning about Volodymyr Shynkaruk's philosophical views, we cannot do this, as his reflections at certain points obviously contradict Volodymyr Shynkaruk's texts.
\end{abstract}

Key word: history of philosophy in Ukraine, modern Ukrainian philosophy, philosophy of Volodymyr Shynkaruk, Kyiv anthropological school.

\section{Introduction}

The legacy of Volodymyr Shynkaruk has become the subject of numerous interpretations in the historical and philosophical, and polemical texts of modern Ukrainian philosophers. The emergence of various interpretations is caused not only by the texts of the classic of modern Ukrainian philosopher and facts from the history of philosophical thought development in Ukraine in the second half of the 20th century, but also by the struggle of various narratives that already exist or are offered by philosophers to tell about the fate of philosophy in Kyiv in Soviet and post-Soviet times. Various interpretations of the history of philosophy in Ukraine in the second half of the 20th century lead to the emergence of different visions of the prospects for the development of philosophical thought today.

Purpose and objectives of the article. Purpose of the article is to analyze the critical analysis of the interpretation of the philosophy of Volodymyr Shynkaruk, which was provided by Vitalii Tabachkovskyi during the discussion about the Kyiv anthropological school, its ideas and significance.

\section{Research methods}

The discussion about the identity of Volodymyr Shynkaruk's philosophy arose in the late 1990s and early 2000 s in connection with the publication by V. Tabachkovskyi of a number of articles and chapters in books devoted to the interpretation of the figure of $\mathrm{V}$. Shynkaruk as the founder of the Kyiv anthropological school. At the same time, V. Tabachkovskyi used the methodology of $\mathrm{V}$. Horskyi, and directly stated about this in the book "In search of unlost time" (Tabachkovskyi, 2002). It is in line of the historical and philosophical methodology of Vilen Horskyi that the institutionalization of the philosophical school, the founder of which was Volodymyr Shynkaruk, is considered. In the discussion that started after the publication of V. Tabachkovskyi's book, the existence of such a school was denied from various methodological positions, or new visions of the phenomenon of the Kyiv anthropological school were created.

The discussion, which arose in 2003 and has not actually been completed to date, revealed different approaches to the very phenomenon of philosophy that 
existed under the Soviet regime, to the meaning and significance of V. Shynkaruk's philosophical ideas. However, in textbooks on the history of philosophy, the narrative of the development of such a philosophical school and its achievements in the transformation of Soviet philosophical discourse remains dominant. In many respects such contradictions are caused by the lack of a comprehensive analysis of V. Shynkaruk's philosophical ideas in their individuality and specificity.

\section{Result and Discussion}

The concept of the Kyiv anthropological school was proposed by the younger generation of philosophers who were part of this school. Vitalii Tabachkovskyi was leading among them. He wrote the book: "In search of unlost time: essays on the creative legacy of Ukrainian philosophers of the sixties", published in 2002 (Tabachkovskyi, 2002).

In this work, Vitalii Tabachkovskyi tried to substantiate and reveal a certain narrative about the Kyiv Philosophical School as the central mainstream in the philosophical sixties, as well as a narrative about the phenomenon of philosophical sixties as a kind of manifestation of liberalism and dissidence regarding the official ideology and philosophy. This narrative was also revealed in the prefaces to the first, second and third volumes of "Vybrani tvory" ("Selected Works") by Volodymyr Shynkaruk (Tabachkovskyi, 2003; Tabachkovskyi, 2004).

It should be noted that the self-reflection of the representatives of the Kyiv Philosophical School includes the reflections of those whom Vitalii Tabachkovskyi and his associates refer to this school. Thus, we have, among other things, reflections of Myroslav Popovych (Popovich, 1997) and Serhii Krymskyi (Krymsky, 2012).

In two articles, Volodymyr Shynkaruk spoke about the "philosophical thaw" of the 1960s and the desire of thinkers to find new ways to develop the philosophy (Shinkaruk, 2004: 57-80). Volodymyr Shynkaruk, Serhii Krymskyi, Myroslav Popovych assign an important role to the figure of Pavlo Kopnin. They speak of Kopnin's views on science and Marxism as open systems, as knowledge the development of which continues; on scientific theories as such, that are able to acquire new features, develop new methodological tools and apply them.

Such a vision was a kind of turning point in the national Soviet philosophy. Until then, Marxism was considered a system in which the ultimate truth was found, and the core idea of the "development" of Marxist philosophy was to clarify this truth. In fact, it was a resemblance of a religious or theological system. According to the reflections of V. Shynkaruk, S. Krymskyi, M. Popovych, the methodological and creative, rather than dogmatic view of Marxism, natural for P. Kopnin, turned out to be extremely important for the Kyiv scientific environment to begin the efficient work.

P. Kopnin's ideas that the development of scientific thinking and philosophy as an ideology was conducted in accordance with the historical and cultural development of mankind proved to be significant. This is most clearly manifested in categories and ideas, as the latter are the core of scientific and philosophical knowledge. The sys- tem of categories and ideas was conceived as evolving and largely dependent on human culture and ideology. This guideline deepened the understanding of the significance of the worldview and allowed to achieve new results, combining ideological, cultural, humanistic components with logic, science and strict rationality.

Of course, these combinations were realized by the philosophers of the Kyiv school in their own way. Over time, some ideas were conceived as ideological. For example, the teachings of Volodymyr Shynkaruk about faith, hope, and love refer to Pavlo Kopnin's reflections on faith as trust, as faith in ideals. The roots of the concepts that researchers of Volodymyr Shynkaruk's work nowadays attribute to the impact of existentialism and world philosophy come precisely from his dialogue with Pavlo Kopnin. The older generation of modern Ukrainian philosophers pays tribute to Pavlo Kopnin.

Vitalii Tabachkovskyi builds his own narrative in such a way that Pavlo Kopnin acts as a forerunner of the entire Kyiv Philosophical School, and the founder, the "patriarch" who constituted this school, is Volodymyr Shynkaruk. It is at this point that there are differences in the narratives of the older generation of philosophers of sixties and the narrative of Vitalii Tabachkovskyi as a representative of the younger generation of Ukrainian philosophers of sixties. The older generation of philosophers sees the founder of the Kyiv Philosophical Schoolin the figure of Pavlo Kopnin, and, from the position of Vitalii Tabachkovskyi, the founder of this school is Volodymyr Shynkaruk.

This discrepancy requires clarification of the reasons for the declaration of a position. We can say that Vitalii Tabachkovskyi moves in the direction of the Christian narrative, which presupposes a "forerunner" and a "Saviour", i.e. one who was the first to establish a systematic philosophical school and allow his "students" to work. But we know that a certain circle was formed when Pavlo Kopnin was recruiting his own staff. Accordingly, a certain philosophical circle developed in Kopnin's time. Despite this, Vitalii Tabachkovskyi attributes the role of "Saviour" to Volodymyr Shynkaruk.

It is alarming that in Tabachkovskyi's book "In search of unlost time: essays on the creative legacy of Ukrainian philosophers of the sixties" there are very few arguments in favour of the central significance of the figure of $V$. Shynkaruk, because many presented reflections are not based on the analysis of the texts of V. Shynkaruk, analysts of his ideas, but are built on the method of analogies, which, as known, is the least evidence-based for the history of philosophy and philosophy in general.

Vitalii Tabachkovskyi reflects on the fact that there are some statements by Shynkaruk about impressions that may indicate certain influences of the ideas of neoMarxism, existentialism, Heidegger. The general disadvantage of the above book by Tabachkovskyi is the author's focus on making certain analogies without referring to specific texts by Shynkaruk or other authors who would testify to the presence of certain influences on the views of Volodymyr Shynkaruk; given that, the analogy is not the final proof. It can be seen as the beginning of a discussion of what, in fact, was the Volodymyr Shynkaruk's 
concept. Analogies can lead to certain ideas, which then need to be proved by analyzing the texts in search of certain ideological influences. For example, Hegel influenced the philosophy of the 20th century, and Tabachkovskyi has the idea that Hegel's influence on Shynkaruk's views was similar. Hypothesis in this way of course has a right to life. However, hypotheses based purely on the application of the method of analogy require systematic verification.

It should be noted that, in general, the book "In search of unlost time: essays on the creative legacy of Ukrainian philosophers of the sixties" caused a huge controversy, which developed in the journal "Kritika" in 2003-2004. The journal published by a well-known literary critic and professor at Harvard University, Hryhoriy Grabovych, issued a review by Volodymyr Verloka (Verloka, 2003). The author responds positively to Tabachkovskyi's book, but says that it represents a somewhat subjective impression, seeks to actualize the meaning of the discussion of the 1960 s - early 1980s for today. Volodymyr Verloka emphasized that Tabachkovskyi's book was designed to give the modern reader an idea of the essence of the controversy of Soviet-era philosophers within the framework of Marxism; also in the Tabachkovskyi's book, from the standpoint of pragmatism, the question of which ideas put forward by the thinkers of the 1960s could be relevant nowadays was considered.

According to Volodymyr Verloka, Vitalii Tabachkovskyi tries to show that the ideas of certain philosophers have not lost their relevance and can be used today. However, such pathos contributes to the ideologisation of historical and philosophical discourse. Vitalii Tabachkovskyi involuntarily inclines to ideologising, though he himself is opposed to any ideologising of philosophical discourse. In this situation, Vitalii Tabachkovskyi ideologises the historical and philosophical discourse and tries to prove that the philosophical pursuits of contemporary thinkers are relevant today.

It is necessary to understand that the mentioned philosophical searches took place in the epoch of industrial civilisation, late modernism, while, as now, we live in the post-industrial, postmodern era. It is obvious that the philosophers of the 1960s - 1980s somewhere foresaw the coming of new times and the need to find humanistic answers to the challenges of scientific and technological revolution, social change. Although the thinkers of the time could hardly have imagined the scale and globality of all these transformations; have imagined that we would find ourselves in a civilization that would be fundamentally different from any modern alternative.

In the 1990s, Volodymyr Shynkaruk thought that the future society would borrow something from both socialism and capitalism, there would be some convergence of the ideas (philosophers of the sixties foresaw these themes in the 1970s). Nowadays we see that if the convergence of ideas takes place, it is done in fundamentally different conditions, the conditions of postmodernism, where any combination of ideas is possible. What for Shynkaruk could be the product of social and philosophical syntheses, for modern reality is the result of a combination, game, mosaic, collage.
We can say that Vitalii Tabachkovskyi himself, because of his desire to update ideas at any cost, is captured by that, and this gives a certain ideological rhetoric to his book. Very often the grains of historical and philosophical analysis are correct, but the rhetoric that develops around them is somewhat idealistic, sometimes even ideological in nature, too emotional.

Vitalii Tabachkovskyi's narrative can be compared with the reflections of the representatives of the older generation of philosophers of the sixties, V. Shynkaruk, M. Popovych, S. Krymskyi. At the same time, it turns out that the mentioned thinkers, in fact, were more restrained in their attitude to the historical and philosophical vicissitudes and more calmly talked about the fate of the Kyiv ideological and philosophical school. The position of $\mathrm{V}$. Shynkaruk, M. Popovych, S. Krymskyi is more balanced and devoid of ideological pathos. Such a position should be a guide that allows to form a more balanced attitude with deep compassionate reflection on all the philosophical thought of the 1960s - 1980s.

The fact that one of Vitalii Tabachkovskyi's students Julia Yemets-Dobronosova wrote an apologetic review of his aforementioned book had a negative role in the controversy. This review was also published in the journal "Kritika" (Yemets-Dobronosova, 2003). This response was extremely positive. It was said that Vitalii Tabachkovskyi's book is devoid of any shortcomings and is extremely relevant; that this work, in fact, represents the Kyiv Philosophical School as one that really existed, had significant achievements and came up with the ideas that metaanthropology offers today.

It should be said that such a review, which was too apologetic, provoked a barrage of criticism from other authors. In the context of the controversy, one of the reviewers wrote a paper stating that in the 1960s - 1980s, no real philosophical discourse was possible at all within the framework of official Soviet philosophy. Everything that happened, allegedly, within the Soviet philosophical discourse, was ideological in nature. All conversations about humanism, about anthropocentrism were tools for power, and power ruled over society purely technocratically without any humanistic and ideological ideas and sentiments.

This response, of course, caused a lively controversy. Numerous thinkers have spoken out in this regard. The statement that attracted additional attention, was that the only real philosopher at that time was Vasyl Semenovych Lisovyi, who remained true to his humanistic views, for which he was arrested (Ponomarev, 2003). Vasyl Lisovyi spent ten years in prison and was unable to work as a philosopher until Perestroika.

Vasyl Lisovyi himself said that it was too optimistic to consider those times as a period when the Kyiv Philosophical School took place (Lisovyi, 2004). Lisovyi noted that if such a school existed, it would be noticed in the West, just as the Tartu Semiotic School was noticed. From the point of view of Vasyl Lisovyi, since this did not happen, the argument about the significance of the Kyiv Philosophical School within the Soviet Union is too weak.

Vitalii Tabachkovskyi himself admits that in 1960s and early 1970s the Kyiv Philosophical School declared itself 
and, as it had an all-Ukrainian scale, was noticeable for Moscow, Leningrad, and other centers of philosophical thought. But, later, new philosophical centers began to appear on the territory of Ukraine, so the significance of the Kyiv Philosophical School was somewhat minimized. In this context, we can mention the circle of Avenir Uiomov in Odesa, the attempts to establish his own philosophical circle in Zaporizhzhya by Heorhii Zinchenko. All these searches took place in the 1960s - 1970s. Vasyl Lisovyi's opinion on ambiguity in the process of assessing the significance of the Kyiv Philosophical School and the narrative about it as an attempt to look at this situation in a somewhat simplified way has a certain rational grain. Since, as we said earlier, Vitalii Tabachkovskyi proposed a certain narrative, and the latter provides for some simplification.

All the above-mentioned controversy began to come to an end when Oleh Khoma on the pages of the same journal "Kritika" remarked on the possibility of the existence of the Kyiv Philosophical School, but not in a strictly institutional sense (Khoma, 2004). The phenomenon of the Kyiv Philosophical School should be considered, rather as a kind of trend, mentality, a certain informal community, which was partially formed in some institutions, but, in general, did not have a clear research position in the presented results. This idea can be deepened in the future.

Turning to the memories and reflections of Myroslav Popovych, we note that he connects the formation of the Kyiv Philosophical School with the writing of a collective work under the direction of Pavlo Kopnin "Logic of Scientific Research" (Kopnin, 1965). Myroslav Popovych speaks of this work as of "our structure of scientific revolutions" (by analogy with the concept of Thomas Kuhn) (Popovich, 1997).

This book is important because it was a collective project in which Kopnin took part together with representatives of the young generation of Kyiv philosophers. At the level of this project, their paradigm of attitude to science, philosophy, dialectics, to the categories of logic has developed. The formed paradigm developed the ideas of Pavlo Kopnin and made the very process of scientific knowledge, formation of hypotheses, substantiation of theories the subject of scientific interest; the phenomenon of merging scientific categories with cultural concepts; studying the nature of the impact on the process of understanding and achieving scientific results (except for logical categories, scientific hypotheses, schemes) of general human culture, which develops our ability to judge, taste. It is extremely important that such a vision connects the ideals of science, which is designed to constantly evolve (and philosophy should promote this development) with the ideals of humanism. To ensure a high culture for the development of science, its humanisation, it is necessary to engage in cultural upbringing and education of the younger generations.

All these discussions are narrative in nature, as the reflections appear as a self-reflection of the events of the 1960 s - 1980s by the participants in the process. In the case of such a comprehension, it is natural that the construction of certain narratives begins; that some of the experiences that accompanied these processes are transmitted; that certain understandings and impressions about the events that took place are revealed. In this way, the fixation of worldview impulses arose at that time. With the help of narratives, historical and philosophical reflections, semi-memoir reflections and recollections, the ideology of the participants of the processes and discussions of that time is transmitted. And also a number of analogies are built; it turns out what those philosophical processes, thoughts, discussions that took place in the 1960s - 1980s were like. Here we can talk about the first stage of reflection, when, in fact, the historical and philosophical process as such has not yet taken place, because the historical and philosophical analysis was carried out on the basis of such impressions.

In the 1990 s and early 2000 s, numerous works by the younger generation of the Sixties and other representatives of the Kyiv Philosophical School (for example, Yevhen Andros and Viktor Andrushchenko) began to reflect on the historical and philosophical foundations of the Kyiv Philosophical School's legacy. These considerations gradually acquire the features of system analysis when referring to texts. In this way, an attempt is made to derive certain concepts from the texts of the representatives of the Kyiv Philosophical School and, accordingly, to present their thoughts on the main characteristics and achievements of this school. In such reflection, the boundaries of memoir, emotionality and immediacy of the world perception are overcome and the transition to an indepth examination and historical and philosophical characteristics of the phenomenon of Kyiv philosophy in the 1960 s - 1980s is conducted. Paradoxically, some points for such a historical and philosophical analysis were laid by Volodymyr Shynkaruk himself. When this analysis begins to deepen and move from the stage of reflection at the level of self-awareness and self-perception to reflection at the level of deep self-understanding, there is a discovery of what the phenomenon of the Kyiv Philosophical School really was.

It is important to emphasize that many distortions of the true meaning of the texts of Kyiv philosophers occurred through reading them not in their own context and meanings, but through guessing what similar philosophical concepts are in world thought. Vitalii Tabachkovskyi's method of analogies and his attempts to look at Volodymyr Shynkaruk's work through the prism of analogies with modern trends develop in the book "In search of unlost time: essays on the creative legacy of Ukrainian philosophers of the sixties", where a separate chapter is devoted to Volodymyr Shynkaruk, and in several prefaces to the three-volume edition of the works of Volodymyr Shynkaruk. The main substantive shortcoming of Tabachkovskyi's analogies and his narratives is their certain contradiction to the texts of Volodymyr Shynkaruk himself. For example, Tabachkovskyi says a lot about the fact that in contrast to the dogmatized system of ideological, school Marxism, Shynkaruk offers a humanistic version of Marxism, which is similar to the work of Western neo-Marxists, and this Shynkaruk's Marxism draws inspiration from the early works of Marx, his "Economic and Philosophical Manuscripts". If we turn to the texts of 
Volodymyr himself, we see that he emphasises that when writing "Economic and Philosophical Manuscripts" Marx was strongly influenced by humanism and anthropologism of Ludwig Feuerbach and did not fully understand the social nature of the ideology, the social nature of philosophy; did not fully realize that alienation can be overcome not by humanizing the ways of human existence, but through class struggle and radical social transformations. Volodymyr repeatedly emphasised in his works that Marxism should be considered in its classical form, which developed in 1848 and later, and not in the form in which Marxism arose (during the writing of "Economic and Philosophical Manuscripts" in 1844), because the Marxist humanism of the period of origin is somewhat incomplete.

In this example, we see the weakness of Tabachkovskyi's interpretation, because the humanism proposed by Shynkaruk may be somewhat similar to the humanism of early Marx, but the ideas of early Marx are criticized by Volodymyr himself. Obviously, the similarities in Shynkaruk's views should not be seen as a dependence or a return to the ideas of early Marx. Being historians of philosophy, we need to look for other reasons and explanations for the views of Volodymyr Shynkaruk, because we have texts that contradict the interpretations of Vitalii Tabachkovskyi.

Vitalii Tabachkovskyi also emphasises that Hegel's texts were of great importance to Shynkaruk, they were for him a "guide" to the world of existential thinking; that Shynkaruk used Hegel's texts similar to those used by the French existentialists. In this case, if we turn to the works of Volodymyr, dedicated to Hegel, in particular, his monographs: "Logic, dialectics and theory of knowledge of Hegel" (1964), "The unity of dialectics, logic and theory of knowledge" (1977), we see that Hegel's idealistic interpretations by French existentialists are criticized and rejected by Shynkaruk as inadequate to Hegel's own views and far from the estimates that philosophy, in terms of materialist dialectics, should give to Hegel.

Moreover, Shynkaruk himself does not come to a detailed analysis of Hegel's interpretation by French and other existentialists (one could say that Hegel's ideas are proposed by Shynkaruk under the guise of critical analysis). Shynkaruk's texts summarise the essence of the existentialist approach to Hegel's interpretation, and then briefly argue why such an interpretation is erroneous. There is clear evidence that Shynkaruk's own dialecticalmaterialist view of Hegel is an alternative and opposite to the interpretations of existentialists (which actualise the idealistic aspects of Hegel's philosophy).

\section{Conclusions}

Despite the desire to positively accept Vitalii Tabachkovskyi's reasoning about Volodymyr Shynkaruk's philosophical views, we cannot do this, as his reflections at certain points obviously contradict Volodymyr Shynkaruk's texts. The task of the historian of philosophy is to give the philosopher-hermeneutician an idea of the life of a particular author; material about the creative legacy of the thinker; understanding the content of his texts and the context in which these works were written.
Also, the historian of philosophy must reveal the meaning of all these points for today. Accordingly, if the author tries to "read" certain ideas that contradict the very texts of the studied philosopher, it means that there is a departure from the positions of historical and philosophical hermeneutics on the position of "school exegesis". The existence of a certain school in the early 2000s is assumed, and the author, in this case Vitalii Tabachkovskyi, tries to "read into" the ideas of this modern school (for example, interest in early Marx, interest in Hegel's interpretation by French existentialists) in the works and intellectual biography of the philosopher (Volodymyr Shynkaruk). This approach is erroneous. And, although it is quite possible that such "reading into" is motivated by good intentions, its flaw, from a historical and philosophical point of view, is too noticeable. Thus, in order to adhere to the principles of the methodology of historical and philosophical hermeneutics, in the strict sense of the word, it is necessary to leave aside the elements of controversy and the desire at any cost to actualize the significance of Volodymyr Shynkaruk's work.

\section{REFERENCES}

Khoma, O. (2004). Post-totalitarian philosophizing. Critique. 3 (77): 18-20 (in Ukrainian).

Kopnin, P.V., Popovich, M.V. (1965). Logic of scientific research. Moscow: Nauka (In Russian).

Krymskyi, S. (2012). Our life-long talk. (A cycle of interviews with T.A. Chaika). Kyiv: Dmitry Burago Publishing House (In Russian).

Lisovyi, V. (2004). Rhetoric instead of argumentation. Critique. 3 (77): 17-18 (in Ukrainian).

Ponomarev, V. (2003). Designing a School. Critique. 12 (74): 28 (in Ukrainian).

Ponomarev, V. (2004). Stumps from the Academy Garden. Critique. 4 (78): 28 (in Ukrainian).

Popovich, M. (1997). P. V. Kopnin: man and philosopher. https://libr.link/uchebniki-istoriya-filosofii/popovich-pvkopninchelovek-31726.html (In Russian).

Shinkaruk, V. (2003) Selected works: in 3 volumes. Vol. 1. Kyiv: Ukrainian Center for Spiritual Culture (in Ukrainian).

Shinkaruk, V. (2003a) Selected works: in 3 volumes. Vol. 2. Kyiv: Ukrainian Center for Spiritual Culture (in Ukrainian).

Shinkaruk, V. (2004). Selected works: in 3 volumes. Vol. 3. Part 1. Kyiv: Ukrainian Center for Spiritual Culture, 2004. Vol. 3. Part 1 (in Ukrainian).

Shinkaruk, V. (2004a). Selected works: in 3 volumes. Vol. 3. Part 2. Kyiv: Ukrainian Center for Spiritual Culture, 2004 (in Ukrainian).

Tabachkovskyi, V. (2002). In search of unlost time: essays on the creative legacy of Ukrainian philosophers of the sixties. Kyiv: Parapan (in Ukrainian).

Tabachkovskyi, V. (2004). Ukrainian personalism of V. Shinkaruk in Shinkaruk V.I. Selected works: in 3 volumes. Vol. 3, Part. 1. Kyiv: Ukrainian Center for Spiritual Culture, P. 5-55 (in Ukrainian).

Tabachkovskyi, V. (2003). Hegel's conceptual landscapes and domestic neo-Marxist phenomenology in Shinkaruk V.I. Selected works: in 3 volumes. Vol. 2. Kyiv: Ukrainian Center for Spiritual Culture, 2004. P. 5-25 (in Ukrainian).

Verloka, V. (2003). In the shadow of flower philosophers. Critique. 10 (72): 17-18 (in Ukrainian).

Verloka, V. (2004). Anthropology of anthropology. Critique. 3 (77): 15 (in Ukrainian).

Yaroshovets, V. (2010). Philosophy as a history of philosophy. Kyiv: Center for Educational Literature (in Ukrainian).

Yemets-Dobronosova, J. (2003). Search for anthropology. Critique. 10 (72): 19-22 (in Ukrainian). 
Анатолій Вовк,

Національний університет біоресурсів і природокористування Украӥни (Київ, Украӥна) e-mail: vovkanatolij2021@gmail.com,ORCID 0000-0002-3636-3773

\section{ІНТЕРПРЕТАЦІЇ ФІЛОСОФСЬКОї СПАДЩИНИ ВОЛОДИМИРА ШИНКАРУКА В РОБОТАХ ВІТАЛІЯ ТАБАЧКОВСЬКОГО}

Виникнення різноманітних інтерпретацій спадщини Володимира Іларіоновича Шинкарука спричинене не лише текстами класика сучасної української філософії та фактами 3 історії розвитку філософської думки в Україні другої половини XX століття, а й боротьбою різних наративів, які вже існують або пропонуються філософами, щоб розповісти про долю філософії в Києві за радянських та пострадянських часів. Дискусія про ідентичності філософії Володимира Шинкарука виникла наприкінці 1990-х - на початку 2000-х років у зв'язку з публікацією В.Г. Табачковським ряду статей та розділів у книгах, присвячених інтерпретації постаті В. Шинкарука як засновника Київської антропологічної школи. Віталій Табачковський намагався обгрунтувати і розкрити певний наратив про Київську світоглядно-філософську школу як про центральний мейнстрім у філософському шістдесятництві, а також наратив про сам феномен філософського шістдесятництва як своєрідний прояв лібералізму та дисидентства відносно офіційної ідеології і філософії. Багато викривлень дійсного значення текстів київських філософів відбувалося через читання їх не у їх власному контексті та значеннях, а через вгадування того, якими є схожі фрілософські концепції у світовій думці. Метод аналогій Віталія Табачковського та його спроби подивитися на праці Володимира Шинкарука крізь призму аналогій із сучасними течіями розвиваються у його книзі та багатьох статтях. При всьому бажанні позитивно прийняти розмірковування Віталія Табачковського про філософські погляди Володимира Шинкарука, ми цього зробити не можемо, оскільки його рефлексії у певних пунктах очевидно суперечать текстам самого Володимира Шинкарука.

Ключові слова: історія фрілософрії в Україні, сучасна українська фрілософрія, фрілософрія Володимира Шинкарука, Київська антропологічна школа.

(C) Anatolij Vovk

Надійшла до редакції: 21.04.2021

Прийнята до друку: 14.06.2021 